\title{
On the Multimedia Teaching in College English Listening*
}

\author{
Xiaoyan Du \\ School of Foreign Languages, Qingdao University of Science and Technology, Qingdao, China \\ Email: Devon_du@126.com
}

\begin{abstract}
With the reform of college English teaching, multimedia-aided listening teaching has become the focus. This paper puts forth the current situation and requirement of college English teaching, gives a brief introduction of constructivism theory of learning, analyses the advantages of multimedia teaching, and proposes some teaching tips with the aid of multimedia in listening class to meet the demands of new curriculum requirement.
\end{abstract}

Index Terms - multimedia, constructivism, listening class, motivation

\section{The Reform of College English Teaching AND the IntRoduction of Multimedia}

After the entry of WTO, the Ministry of Education launched a project named "Teaching Quality and Teaching Construction of Higher Education", among which the curriculum requirement for college English teaching released in Sept.26, 2007 is one of the top priorities. This latest curriculum states that the requirement of English teaching for college stage should be divided into three levels, that is, general requirement, high requirement and higher requirement respectively. The design of the curriculum should take the requirement of the cultivation of listening and speaking into adequate consideration and distribute enough credit and time to it. Sufficient advanced information technology should be fully employed. More computer-based or Internet-based curricula should be developed and utilized to provide better environment and condition for language acquisition of students. This pattern is a new integrated way to help Chinese college students to meet the above new requirement. It emphasizes autonomous learning ability and individualized teaching to bring computer's advantages into full play. With that, students can combine their personal features and teachers' guidance to improve their comprehensive ability, thus, achieve the best effect of study.

In 2005, the CET (College English Test) was reformed. The biggest change was in listening part which makes up $35 \%$ of the whole test, but it only originally accounted for $20 \%$ in the past. Thus, the teaching idea must be changed accordingly, and the teaching method must be adjusted. The focus should be placed on practical use and the training of listening must be emphasized. The introduction and use of multimedia technology for the English class has crucial practical value and profound meaning.

No matter whether it is computer-based curriculum or traditional-classroom-based curriculum, it should involve great distinguishing features and full consideration for students with high English proficiency and relatively low proficiency as well. It should not only set a solid base for students, but train their practical use of English, particularly in speaking and listening.

When computer-based curriculum is mentioned, it is easily acknowledged that the computer is the synonym of multimedia with various Internet resources. To be exact, multimedia is media and content that uses a combination of different content forms. The term is used in contrast to media which only use traditional forms of printed or hand-produced material. Multimedia includes a combination of text, audio, still images, animation, video, and interactivity content forms.

\section{CONSTRUCTIVISM THEORY OF LEARNING}

Constructivism is a philosophy of learning founded on the premise that, by reflecting on our experiences, we construct our own understanding of the world we live in. Each of us generates our own "rules" and "mental models," which we use to make sense of our experiences. Learning, therefore, is simply the process of adjusting our mental models to accommodate new experiences. Constructivism, a further development of behaviorism and cognitive theory, provides great theoretical supports for application of multimedia in English teaching. Constructivism is a view of learning based on the belief that knowledge is not a thing that can be simply given by the teacher at the front of the classroom to students in their desks. Rather, knowledge is constructed by learners through an active, mental process of development. Social constructivism views each learner as a unique individual with unique needs and backgrounds. The learner is also seen as complex and multidimensional. Social constructivism not only acknowledges the uniqueness and

\footnotetext{
* This paper is partial achievements of the foreign language teaching research project of Foreign Language Teaching and Research Press. No. 2009WYS04
} 
complexity of the learner, but actually encourages, utilizes and rewards it as an integral part of the learning process. Furthermore, it is argued that the responsibility of learning should reside increasingly with the learner. Social constructivism thus emphasizes the importance of the learner being actively involved in the learning process, unlike previous educational viewpoints where the responsibility rested with the instructor to teach and where the learner played a passive, receptive role. Von Glasersfeld emphasizes that learners construct their own understanding and that they do not simply mirror and reflect what they read. Knowledge is thus a product of humans and is socially and culturally constructed.

With this theory, instructors have to adapt to the role of facilitators and not teachers. So this requires teaching process should be student-oriented. The development of multi-media materialized this theory. With multi-media, students can absorb information extensively; their interest and motivation can be promoted dramatically; and the teaching target can be achieved fully.

\section{The AdVANTAges of Multimedia TEACHING}

Listening in English teaching has always been important and difficult. The traditional "trilogy" of English teaching, namely, listening-correcting-listening, has been behind the pace of modern teaching to mobilize enthusiasm of students, and it can only achieve a rigid response. Listening can be optimized by multimedia teaching.

\section{A. The Application of Multimedia can Stimulate Students'Interest and Improve Their Language Sense}

Interest is the best teacher. To arouse students' interest, multimedia is a good instrument. Cognitive psychology maintains that the learning of English should combine language and image, and multimedia can integrate vision, text, picture and audio actively, to stimulated the nerve cell of brain of students and promote their abstract thinking and thinking in terms of images. The application of multimedia can help make a better learning atmosphere. Overwhelmed in a multimedia environment, students can avoid the embarrassment when fail to answer teacher's questions. They can actively get involved in the material prepared for their language acquisition. The information flow is huge, and their language sense can be sharpened and improved. Thus, with this interactive, virtual atmosphere, students can get knowledge in a pleasant environment and apply them easily, which can help their full development.

\section{B. The Application of Multimedia can Help Cultivate the Intercultural Communication}

Learning a language is tightly connected with its culture. Language is the carrier of the culture, and culture is the reflection of the language. Therefore, to learn English well need the integration of English and the culture of English-speaking countries. With multimedia, students can have more chances to be exposed to English culture directly or indirectly, which cannot be achieved from traditional class.

\section{The Application of Multimedia can Strengthen Students' Comprehension and Understanding}

Learning is a process, in which all senses are involved. Sight and hearing accounts for $94 \%$ of the comprehension of learning materials, among which sight makes up 83\%, and hearing $11 \%$. When hearing and sight combine, the effect is strikingly improved. The application of multimedia motivates the senses, especially sight and hearing, which effectively strengthen students' comprehension and understanding.

\section{The Application of Multimedia can Improve Teaching Quality}

The communicative approach of educational psychology states that there are two key factors that determine the English learning, learning motivation and attitude. Active learning motivation and attitude can help learners acquire the target language proficiency. The stronger learning motivation is, the more active leaning becomes, and the better learning effect, vice versa. The application of multimedia arouses the motivation of learners, and can promote their learning from the internal cause.

\section{Teaching Method With Multimedia}

\section{A. Sufficient Preparation before Class}

Multimedia listening class does not mean the teacher just use the mouse to show some movie clips or listening materials to students. This new instrument brings more challenges to teachers. According to every teaching unit, the teacher should select suitable material before class. The material should be new, comprehensive, to the point of the book, and should also arouse students' interest. They can be current news, classic movie clips, nice songs, etc. All these should have some connection with the teaching theme of the respective class.

\section{B. Play and Check}

Some students regard listening class as a relatively easy class, if the teachers only focus on playing video or listening material and then simply check the answers. The students feel no pressure, as long as they are not challenged. Then some students begin to neglect the listening class, which is a huge loss for them and also is the result of teachers' wrong teaching method. In the class, teacher can divide students into several groups, and each group is assigned a task. When they are shown the material, every member is involved in with some certain tasks. With this method, they can watch or 
listening more effectively. When students fail to finish their tasks, it means the material is difficult for them. Then the teacher can replay it and explain some key words, slangs or long sentences. If students can easily answer the questions, the teacher can raise some deeper questions for them to discuss to improve their oral English. Easy material can boost students' confidence, and give them a sense of achievement. While the difficult ones can challenge their ability, and give them more space to improve to a higher level.

\section{Effective After-class Assignments}

The improvement of listening skill cannot be achieved through a listening class once every week or every two weeks in some colleges. The main task should be left after class. Teacher should assign some homework for students to listen and practice after class. The assignment should be specific and easy to check. Then the students can have a clear idea on what to listen and how to listen. For some students with higher demand and desire, the teacher can guide them in a broad direction. The development of network technology provides students with great resources which fully reflect the main idea of extensiveness in reading. Under the teacher's guidance, students, according to their own preferences, read freely and gradually form a cultural awareness of English, thereby to learn English and foreign culture well, which also embodies the idea of students-centered.

\section{CONCLUSION}

Besides the benefits from application of multimedia, there are still some negative effects of multimedia in English teaching. Without a standard and effective courseware design, the teaching content and arrangement will be ambiguous; Students are easily distracted. Because there exist a lot of pictures, sound and cartoon which cause over-stimulation and partial use of senses, thus, students can easily be distracted from teaching content and lose their concentration.

What teachers and educators should do is to improve professional quality and to cultivate themselves with modern educational theories so that they can make full and proper use of multimedia to aid English teaching and avoid the negative influence of the use of multimedia.

The good use of the multimedia teaching method is an important way to optimize the English teaching results. While handling classes, teachers should use the teaching method of the multimedia actively to improve the teaching quality of English. But it can't be abused. Teachers must choose and use the audio-visual education program media rationally according to the contents of the text, so that they can achieve the goal of optimizing English teaching.

Multimedia teaching makes full use of its advantages to convey information, enhance the interaction between students and teachers, and combine listening, watching and speaking effectively to make a comprehensive teaching pattern which offers positive instrument for modern English teaching. This pattern makes up the disadvantages of traditional English class, and boosts the listening and speaking skill of students and ultimately achieves the better teaching target.

\section{REFERENCES}

[1] Fan lin \& Zhan Qiyun. (2003). The combination of Constructivism and College English Teaching Reform in Foreign Languages and Their Teaching. 2003 (4): 28-32

[2] Krashen, Stephen D. (1988). Second Language Acquisition and Second Language Learning. New York: Prentice-Hall International .

[3] Rod, Ellis. (1985). Understanding Second Language Acquisition. Oxford: Oxford University Press.

[4] Wu Xiaoyan. (2006). The Enlightenment of Constructivism Theory on English Teaching in Foreign Languages and Their Teaching. 2006(2):33-35

[5] Xiu yuezhen. (2006). The study of English Teaching Reform with Internet Multimedia. Beijing: Tsinghua University Press.

\footnotetext{
Xiaoyan Du was born in Weifang, China in 1976. She received her M.A. degree in linguistics from Ocean University of China in 2010 .

She is currently a lecturer in the School of Foreign Languages, Qingdao University of Science and Technology, Qingdao, China. Her research interests include translation studies and second language acquisition.
} 